\title{
Javna nabava pravnib usluga u Hrvatskoj
}

\author{
Mirna Vlabović" \\ Jelena Arambašic **
}

UDK

Preliminary scientific report / prethodno znanstveno priopćenje Received / primljeno: 16.3.2017. Accepted / prihvaćeno: 11.9.2017.

U prvom dijelu rada analiziraju se odredbe novog Zakona o javnoj nabavi (NN 120/16) koje se primjenjuju na javnu nabavu pravnih usluga u Hrvatskoj te se uspoređuju s pravnim uređenjem važećim do kraja 2016. Prijašnji zakon za javnu je nabavu pravnih usluga predviđao mogućnost provođenja tzv. posebnog postupka, dok novi zakon tu mogućnost otklanja, ali zadržava pregovarački postupak bez prethodne objave poziva na nadmetanje. U drugom dijelu rada analiziraju se podaci o javnim nabavama pravnih usluga $\mathrm{u}$ Hrvatskoj u razdoblju 2012.-2016. te se izvode zapažanja o transparentnosti i tržišnoj koncentraciji na tržištu javne nabave pravnih usluga.

Ključne riječi: javna nabava, pravne usluge, tržišno natjecanje, koncentracija, transparentnost

* Mirna Vlahović, studentica poslijediplomskog doktorskog studija trgovačkog prava i prava društava na Pravnom fakultetu Sveučilišta u Zagrebu (doctoral student of commercial and company law at the Faculty of Law, University of Zagreb, Croatia, e-mail: mirna. vlahovic@gmail.com)

** Jelena Arambašić, studentica poslijediplomskog doktorskog studija trgovačkog prava i prava društava na Pravnom fakultetu Sveučilišta u Zagrebu (doctoral student of commercial and company law at the Faculty of Law, University of Zagreb, Croatia, e-mail: j.arambasic1@yahoo.com) 


\section{Uvod}

Pripadnicima slobodnih zanimanja, a u tu kategoriju pripada odvjetništvo, jamče se brojna prava, poput ekskluzivnog prava pružanja usluga. Međutim, kao protuteža posebnim pravima, za pripadnike slobodnih zanimanja vrijedi posebna regulacija, nastala zajedničkim reguliranjem države i samoregulativnih profesionalnih tijela, koja je najčešće stroža od regulacije koja se odnosi na ostale poduzetnike. Ta posebna regulacija u određenim stavkama odstupa od, primjerice, pravila o zaštiti tržišnog natjecanja ili pravila o javnoj nabavi koja vrijede za ostale poduzetnike.

Cilj je rada prikazati posebnosti pravnog uređenja javne nabave pravnih usluga u Hrvatskoj, osobito vrsta postupaka koji stoje na dispoziciji javnim i sektorskim naručiteljima. Javna nabava pravnih usluga u Hrvatskoj do 2017. bila je regulirana Zakonom o javnoj nabavi (NN 90/11, 83/13, 143/13, 13/14), a od 1. siječnja 2017. na snazi je novi Zakon (Zakon o javnoj nabavi, NN 120/16), koji uređenje usklađuje s Direktivom 2014/24/ EU Europskog parlamenta i Vijeća od 28. veljače 2014. o javnoj nabavi i o stavljanju izvan snage Direktive 2004/28/EZ. Prijašnji je Zakon javnim naručiteljima dopuštao mogućnost provođenja tzv. posebnog postupka za nabavu usluga iz Dodatka II. B, u koji su pripadale pravne usluge. Novi Zakon tu mogućnosti otklanja, a definira posebnosti za nabavu pravnih usluga u okviru normalnih postupaka javne nabave. Prijašnja direktiva i prijašnji Zakon sadržavali su Dodatak II. B i za tamo navedene usluge predviđali poseban postupak, uz objašnjenje da se zbog svojih posebnosti te usluge smatraju manje prikladnima za normalne postupke javne nabave. Odredbe o posebnom postupku činile su ga najmanje transparentnim od svih uređenih postupaka javne nabave. U radu će se usporediti odredbe koje su važile do kraja 2016. s odredbama nove direktive i novog Zakona o javnoj nabavi.

Načelo tržišnog natjecanja u javnoj nabavi u ekonomskom smislu podrazumijeva i načelo ne-diskriminacije, tj. jednakog tretmana. Konkurencija na tržištu na kojem sudjeluje javni sektor smatra se manje razvijenom od one u privatnom sektoru, a uzroci ograničene konkurencije su izraženije nesavršene informacije, prepreke ulasku i izlasku dobavljača na tržište i monopol. Dodatne poteškoće proizlaze iz funkcije javne nabave koja mora podmiriti tržišno oprečne ciljeve (Budak, 2016., str. 8). Svako ograničavanje pristupa tržištu, pa tako i značajnom tržištu javnih nabava, isključuje iz tržišne utakmice potencijalno konkurentnije gospodarske subjekte. Zatvaranje tržišta javnih nabava dovodi do formiranja monopola i sindroma »dvorskih dobavljača« (Budak, 2008., str. 151-171). Zbog ka- 
rakteristika posebnog postupka javne nabave, pretpostavka je da on dovodi do ograničavanja tržišnog natjecanja. Također, pretpostavka je da dovodi do netransparentnosti procesa javne nabave. Transparentnost procesa javne nabave podrazumijeva njegovu otvorenost i nediskriminaciju glede informacija koje moraju biti svima jednako dostupne, pouzdane i pravovremene. Pokazatelji transparentnosti javne nabave polaze od poželjne situacije u kojoj se što veći udio transakcija obavlja otvorenim postupcima javne nabave (Budak, 2016., str. 9).

Kako bi se testirale navedene pretpostavke, uz analizu pravnih propisa $\mathrm{u}$ radu je provedena i statistička analiza podataka o javnoj nabavi pravnih usluga u razdoblju 2012.-2016. kako bi se ustanovilo kakva je bila transparentnost postupaka i razina konkurencije na tržištu javne nabave pravnih usluga u tom razdoblju.

\section{Pravni okvir javne nabave u Hrvatskoj}

Javna nabava pravnih usluga u Hrvatskoj regulirana je Zakonom o javnoj nabavi (NN 120/16). Pored toga, javna nabava uređena je i mnogim uredbama Vlade koje u detalje reguliraju pojedine aspekte postupka javne nabave. Značajno je istaknuti Uredbu o načinu izradbe i postupanja s dokumentacijom za nadmetanje i ponudama (NN 10/12) i Uredbu o objavama javne nabave (NN 10/12). Također, na javnu nabavu u Hrvatskoj primjenjuje se i pravna stečevina Europske unije, odnosno nekoliko direktiva koje tretiraju materiju javne nabave. Za pravne usluge važna je Direktiva 2014/24/EU Europskog parlamenta i Vijeća od 28. veljače 2014. o javnoj nabavi i o stavljanju izvan snage Direktive 2004/28/EZ. Nadalje, za postupak javne nabave relevantne su vrijednosti europskih pragova, a te se vrijednosti uzimaju iz Direktive 2014/24/EU. Europska komisija njihove iznose revidira uredbama svake dvije godine. Posljednja je donesena krajem 2015. (Uredba Komisije (EU) 2015/2342 od 15. prosinca 2015. o izmjeni Direktive 2004/18/EZ Europskog parlamenta i Vijeća u vezi s pragovima primjene za postupke dodjele ugovora). Potom se navedeni europski pragovi preračunavaju u odgovarajuće vrijednosti u kunama, što Europska komisija objavljuje u obliku priopćenja u Službenom listu Europske unije koje je doneseno u prosincu 2015. (Priopćenje Komisije - odgovarajuće vrijednosti europskih pragova iz direktiva 2014/23/EU, 2014/24/EU i 2014/25/EU Europskog parlamenta i Vijeća).

$\mathrm{S}$ obzirom na to da su u radu analizirani postupci javne nabave pravnih usluga provođeni u periodu 2012.-2016., analizirat će se odredbe Zakona 
o javnoj nabavi (NN 90/11, 83/13, 143/13, 13/14 - dalje ZJN-2011), kao i novog Zakona o javnoj nabavi iz 2017. (NN 120/16 - dalje ZJN-2017) te odredbe obaju direktiva Europske komisije.

\subsection{Zajedničke odredbe ZJN-2011 i novog ZJN-2017}

Na javnu nabavu pravnih usluga primjenjuje se Zakon o javnoj nabavi, koji predstavlja općenormativni okvir kojim je uređen sustav javne nabave u Republici Hrvatskoj. Njime se uređuju postupci sklapanja ugovora o javnoj nabavi i okvirnih sporazuma radi nabave robe, radova ili usluga, pravna zaštita u vezi s tim postupcima i nadležnost središnjeg tijela državne uprave nadležnog za sustav javne nabave.

Predmet Zakona o javnoj nabavi, definiran u čl. 1. te čl. 338.-345., jesu pravila o postupku javne nabave robe, radova ili usluga koji provodi javni naručitelj (državna tijela; jedinice lokalne i regionalne samouprave; tijela javnog prava i udruženja koje je osnovalo jedno ili više prije navedenih tijela) ili sektorski naručitelj, kada sklapa ugovore o javnoj nabavi robe, usluga i radova za potrebe obavljanja sektorskih djelatnosti (u području plina i toplinske energije; električne energije; vodnog gospodarstva; usluga prijevoza; zračnih, morskih i riječnih luka; poštanskih usluga; vađenje nafte i plina te istraživanja ili vađenja ugljena ili drugih krutih goriva).

Pragovi primjene Zakona, definirani u čl. 12.-14., jesu ovi (procijenjene vrijednosti izražene su bez poreza na dodanu vrijednost):

- Na usluge procijenjene vrijednosti do $200.000 \mathrm{kn}$ (tzv. bagatelna nabava) Zakon se ne primjenjuje, a pitanja nabave do te vrijednosti uređuje naručitelj svojim aktom.

- Nabava usluga procijenjene vrijednosti veće od 200.000 kn, a manje od europskog praga smatra se nabavom male vrijednosti.

- Nabava usluga vrijednosti jednake ili veće od europskog praga smatra se nabavom velike vrijednosti.

Trenutačni europski prag za javnu nabavu pravnih usluga od RH, državnih tijela, jedinica lokalne i područne samouprave i pravnih osoba koje su osnovane radi zadovoljavanja potreba u općem interesu (a nemaju industrijski ili trgovački značaj) jest 209.000 eura, odnosno 1.593 .688 kuna. $\mathrm{Na}$ ugovore o javnim uslugama koje sklapaju sektorski naručitelji (a to su pravne osobe industrijskog ili trgovačkog značaja) primjenjuje se prag od 418.000 eura, odnosno 3.187.375 kuna. Dakle, ako je procijenjena vrijednost nabave jednaka ili veća od navedenih iznosa, nabavlja se kroz 
postupak velike vrijednosti, a ako je manja od navedenih iznosa, nabavlja se kroz postupak male vrijednosti.

Tablica 1. Pragovi primjene Zakona o javnoj nabavi na javnu nabavu pravnib usluga

\begin{tabular}{|c|l|l|}
\hline $\begin{array}{c}\text { Bagatelna } \\
\text { nabava }\end{array}$ & \multicolumn{1}{|c|}{ Nabava male vrijednosti } & \multicolumn{1}{c|}{ Nabava velike vrijednosti } \\
\hline$>200.000 \mathrm{kn}$ & $\begin{array}{l}200.000 \mathrm{kn}-1.593 .688 \mathrm{kn} \\
200.000 \mathrm{kn}-3.187 .375 \mathrm{kn}(\mathrm{za}\end{array}$ & $\begin{array}{l}<1.593 .688 \mathrm{kn} \\
<3.187 .375 \mathrm{kn} \text { (za sektorske } \\
\text { naručitelje) }\end{array}$ \\
\hline
\end{tabular}

Izvor: Izradile autorice na temelju Priopćenja Komisije - odgovarajuće vrijednosti europskih pragova iz direktiva 2014/23/EU, 2014/24/EU i 2014/25/EU Europskog parlamenta i Vijeća

Razlike između postupaka nabave usluga male i velike vrijednosti većinom leže u rokovima (za dostavu ponude, mirovanje, žalbu itd.). U Zakonu o javnoj nabavi pravne su usluge svrstane u usluge iz Priloga X. Društvene i druge posebne usluge, a do stupanja na snagu novog zakona te su usluge bile svrstane u Dodatak II. B. U Pravilniku o primjeni jedinstvenog rječnika javne nabave (NN 6/12), u Prilogu I. A Glavni rječnik, pravne usluge obuhvaćene su CPV oznakama od 79111000-5 do 7914000-7 te 75231100-5:

- 79100000-5 Pravne usluge

- 79110000-8 Usluge pravnih savjeta i zastupanja

- 79111000-5 Usluge pravnih savjeta

- 79112000-2 Usluge pravnog zastupanja

- 79112100-3 Usluge zastupanja dionika

- 79120000-1 Savjetodavne usluge na području patenata i autorskih prava

- 79121000-8 Savjetodavne usluge na području autorskih prava

- 79121100-9 Savjetodavne usluge na području autorskih prava na programsku podršku

- 79130000-4 Usluge pravnog dokumentiranja i ovjeravanja

- 79131000-1 Usluge dokumentiranja

- 79132000-8 Usluge ovjeravanja

- 79132100-9 Usluge ovjeravanja elektroničkog potpisa

- 79140000-7 Usluge pružanja pravnih savjeta i informacija

- 75231100-5 Upravne usluge povezane sa sudovima (dodano ZJN-2017). 
Do sada navedene odredbe ZJN-2017 ne razlikuju se od odredbi prijašnjeg Zakona. Međutim, postupak nabave izmijenjen je novim Zakonom. Budući da je u radu provedena statistička analiza postupaka provedenih od 2012. do 2016., potrebno je promotriti prijašnje uređenje, kao i novine koje donosi Zakon iz 2017.

\subsection{Posebni postupak po ZJN-2011}

Odjeljak 4. glave 1. dijela 2. ZJN-2011 bavio se uređenjem sklapanja ugovora o javnim uslugama. Zakon je u čl. 43. određivao da se za sklapanje ugovora o javnim uslugama iz Dodatka II. B javni naručitelji mogu odlučiti hoće li provesti:

- jedan od postupaka javne nabave: otvoreni (u kojemu svaki zainteresirani gospodarski subjekt može podnijeti ponudu), ograničeni (u kojemu svaki zainteresirani gospodarski subjekt može zatražiti sudjelovanje u postupku, pri čemu samo oni gospodarski subjekti koje naručitelj pozove mogu podnijeti ponudu), pregovarački (u kojemu se naručitelj obraća gospodarskim subjektima po vlastitom izboru i pregovara o uvjetima ugovora s jednim gospodarskim subjektom ili s više njih) s prethodnom objavom ili bez prethodne objave poziva na nadmetanje, natjecateljski dijalog (u kojemu svaki gospodarski subjekt može zatražiti sudjelovanje, pri čemu javni naručitelj s odabranim natjecateljima vodi dijalog s ciljem razvijanja jednog ili više prikladnih rješenja koja mogu udovoljiti njegovim zahtjevima i na temelju kojih će odabrani natjecatelji biti pozvani da podnesu ponude);

- poseban postupak opisan u čl. 44. Zakona.

Ukratko, o razlici između navedenih postupaka može se reći da je otvoreni najviše, a posebni najmanje transparentan. Posebni postupak, koji je bio rezerviran za usluge iz Dodatka II. B, u koji su pripadale i pravne usluge, tekao je na sljedeći način (čl. 44.):

1. Naručitelj objavljuje zahtjev za prikupljanje ponuda na internetskim stranicama, čime započinje postupak. Zahtjev mora biti dostupan na internetskim stranicama najmanje 60 dana od dana objave.

2. Istodobno s objavljivanjem zahtjeva za prikupljanje ponuda na internetskim stranicama naručitelj može uputiti zahtjev za prikupljanje ponuda određenom broju gospodarskih subjekata po vlastitom izboru.

3. Broj gospodarskih subjekata kojima naručitelj upućuje zahtjev za prikupljanje ponuda ne smije biti manji od tri. Ovisno o prirodi usluge o 
kojoj je riječ, uključujući i razinu tržišnog natjecanja u tom području, broj gospodarskih subjekata može biti manji od tri.

4. Iznimno, naručitelj nije obvezan objaviti zahtjev za prikupljanje ponuda ako je to u suprotnosti s posebnim propisom ili pravilima kojima je regulirano obavljanje određenih usluga. U tom slučaju naručitelj upućuje zahtjev za prikupljanje ponuda u skladu sa točkama 2. i 3.

5. Naručitelj izrađuje zapisnik o pregledu i ocjeni ponuda te odabire najpovoljniju ponudu sukladno kriteriju za odabir ponude.

6. Nakon odabira naručitelj može objaviti prethodnu obavijest o namjeri sklapanja ugovora.

7. Ako naručitelj ne objavi prethodnu obavijest o namjeri sklapanja ugovora, donosi odluku o odabiru koju dostavlja ponuditeljima.

8. Naručitelj je obvezan za svaki sklopljeni ugovor odnosno okvirni sporazum poslati na objavljivanje obavijest o sklopljenom ugovoru.

Dakle, javnim i sektorskim naručiteljima davala se mogućnost da zahtjev za prikupljanje ponuda ne objave na internetskim stranicama nego, da ga pošalju samo jednom pružatelju pravnih usluga, a potom odluku o odabiru tog ponuditelja pošalju tom istom ponuditelju te obavijest o sklopljenom ugovoru objave u Elektroničkom oglasniku javne nabave.

\subsection{Mišljenje Hrvatske odvjetničke komore i mišljenje Uprave za sustav javne nabave}

O provedbi postupka javne nabave pravnih usluga mišljenje su donijele Uprava za sustav javne nabave (USJN) i Hrvatska odvjetnička komora. USJN je 2013. objavio svoje mišljenje (Primjena postupka nabave za usluge iz Dodatka II. B za pravne usluge), u kojemu ističe da je ZJN-2011 uveo značajne novine pri sklapanju ugovora o javnim uslugama iz Dodatka II.B Zakona.

USJN ističe da je normiranjem kojim se omogućuje provođenje jednog od postupaka javne nabave ili posebnog postupka iz čl. 44. ostvaren važan iskorak pri provedbi postupaka nabave za usluge iz Dodatka II. B Zakona u kojima je dosadašnja praksa upozoravala na određene probleme u ostvarivanju adekvatne razine transparentnosti i tržišnog natjecanja. USJN u svom se mišljenju poziva na mišljenje Hrvatske odvjetničke komore, u kojem stoji da, sukladno rješenju Ustavnog suda RH (U-I-23/1999. od 20. 4. 2000.), odvjetnička djelatnost ne predstavlja gospodarsku djelatnost i ne može zbog svojih specifičnosti biti podvrgnuta tržišnim zakonitostima te 
da specifična pravila struke položaj odvjetništva čine bitno drugačijim od položaja gospodarskih djelatnosti na tržištu, čime se ono izdvaja od pravila koja vladaju u gospodarstvu u kojem je profit, uz poštovanje ustavnih načela i prava, osnovni cilj.

Međutim, iznenađuje ovo stajalište Ustavnog suda, budući da je izraženo 2000., nakon presude Europskog suda u slučaju Höfner iz 1991., kada su kao poduzetnici određeni svi subjekti uključeni u gospodarsku djelatnost (a svaka djelatnost nuđenja dobara ili usluga na određenom tržištu jest gospodarska djelatnost), bez obzira na pravni status, način financiranja i namjeru ili činjenicu ostvarivanja dobiti (Vlahović, 2013, str. 38). Naknadno je definiciju iz presude Höfner Europski sud upotrijebio i u presudi u slučaju Wouters 2002., kada se pred Europskim sudom postavilo pitanje smatraju li se članovi odvjetničke komore poduzetnicima. Odvjetnici nude pravnu pomoć za određenu naknadu i sami snose financijski rizik poslovanja. Stoga odvjetnici obavljaju ekonomsku aktivnost pa se, usprkos javnom interesu za njihovu djelatnost i korist cjelokupnoj zajednici, smatraju poduzetnicima u smislu čl. 101., ${ }^{1} 102 .{ }^{2}$ i $106 .{ }^{3}$ Ugovora o funkcioniranju Europske unije (Vlahović, 2013, str. 13).

Bez obzira na to, Uprava za sustav javne nabave misli, da naručitelji mogu za nabavu određenih pravnih usluga, s obzirom na njihovu prirodu, uključujući i razinu tržišnog natjecanja u području pružanja tih usluga, primijeniti čl. 44/5. Zakona. U tom slučaju, naručitelji mogu postupiti na sljedeći način: a) nisu obvezni objaviti zahtjev za prikupljanje ponuda na svojim internetskim stranicama, i b) upućuju zahtjev za prikupljanje ponuda za pravne usluge, pri čemu broj odvjetnika kojima se upućuje zahtjev može biti manji od tri, tj. zahtjev se može uputiti i samo jednom odvjetniku, odvjetničkom uredu ili društvu. USJN posebno napominje da, prilikom nabave pravnih usluga, naručitelji na opisani način smiju nabavljati samo usluge koje pružaju isključivo odvjetnici kao oblike pravne pomoći temeljem Zakona o odvjetništvu, a sukladno Tarifi o nagradama i naknadi troškova za rad odvjetnika: a) davanje pravnih savjeta i mišljenja; b) sastavljanje isprava (ugovori, oporuke, izjave i dr.); c) sastavljanje tužbi, žalbi, prijed-

1 Čl. 101. UFEU govori o zabranjenim sporazumima među poduzetnicima, odlukama udruženja poduzetnika i usklađenom djelovanju.

2 Čl. 102. UFEU govori o zlouporabi vladajućeg položaja jednog poduzetnika ili više njih.

${ }^{3}$ Čl. 106. UFEU govori o položaju javnih poduzeća i poduzeća kojima države članice dodjeljuju posebna prava ili isključiva prava te poduzećima kojima je povjereno obavljanje usluga od općeg gospodarskog interesa ili koja su po svojoj naravi monopoli koji ostvaruju prihod. 
loga, zahtjeva, molbi, izvanrednih pravnih lijekova i drugih podnesaka; i d) zastupanje stranaka.

Sukladno tome, ovaj način nabave naručitelj ne smije primijeniti za nabavu, primjerice, savjetodavnih usluga (koje nisu obuhvaćene tarifiranom uslugom pravnih savjeta i mišljenja), izrade studija, analiza i drugih usluga, za koje se kao ponuditelji ili natjecatelji mogu javiti odvjetnici, ali i drugi gospodarski subjekti.

\subsection{Novine Direktive 2014/24/EZ u odnosu prema Direktivi 2004/18/EZ}

Postupak javne nabave regulira Direktiva 2014/24/EU o javnoj nabavi (koja je zamijenila Direktivu 2004/18/EU), s ciljem moderniziranja i koordiniranja postupka javne nabave u državama članicama. Prije donošenja nove Direktive, Europska je komisija 2011. objavila Zelenu knjigu o modernizaciji postupka jarne nabave u EU - prema efikasnijem europskom tržištu javne nabave, a potom i Prijedlog nove direktive. U točki 10. uvodnog dijela Prijedloga direktive stoji da su rezultati ocjene učinka i efektivnosti zakonodavstva EU-a, koje regulira javnu nabavu, pokazali da su određene usluge (a tu se navode i pravne usluge) isključene iz pune primjene Direktive te da bi trebala biti razmotrena puna primjena Direktive. Stoga, Prijedlog direktive nije sadržavao popis usluga iz Priloga II. B, koji je sadržavala Direktiva 2004/18/EZ, na koje se primjenjivao posebni režim.

Na taj je prijedlog Vijeće odvjetničkih komora Europe (CCBE) 2012. dalo svoju kritiku, i to osobito o otklanjanju pojednostavljene procedure javne nabave pravnih usluga. Naime, prema Direktivi 2004/18/EZ, pravne usluge nisu bile podložne punom postupku javne nabave. Pravne su usluge bile uključene u Prilog II. B Direktive 2004/18/EZ te je ona odredila da se na njih primjenjuju samo čl. 23. i 35., koji reguliraju specifikacije u dokumentaciji kojom se definiraju tražene karakteristike usluga te objave obavijesti ili poziva na nadmetanje. Prijedlog nove direktive otklonio je mogućnost pojednostavljene procedure javne nabave pravnih usluga, međutim CCBE je apeliralo na institucije EU-a da zadrže postojeće uređenje ili ga zamijene nekim koje će imati isti učinak, odnosno koje će očuvati poseban položaj pravnih usluga. Uređenje prema Direktivi 2004/18/EZ odgovaralo je uređenju prema hrvatskom ZJN-2011, pa je javnim tijelima davalo diskrecijsko pravo neobjavljivanja zahtjeva i neprimjenjivanja uobičajenog postupka javne nabave (kako je o posebnom postupku već objašnjeno). CCBE je tvrdio da, po njegovu saznanju, s postojećim uređenjem 
nema nikakvih problema te da ne postoje dokazi lošeg funkcioniranja u državama članicama. Kritizirao je nov prijedlog ističući snažan osobni karakter pravnih usluga. Također, isticao je deontološka pravila obavljanja odvjetničke profesije, obvezu čuvanja profesionalne tajne, povjerljivost i druge profesionalne standarde koje valja očuvati. Vijeće je smatralo da će primjena uobičajene procedure javne nabave dovesti do natjecanja u cijenama i pada kvalitete pravnih usluga.

Nova Direktiva donesena je 2014., a u točki 42. uvodnog dijela ističe se da bi »države članice trebale biti u mogućnosti predvidjeti korištenje natjecateljskog postupka uz pregovore ili natjecateljskog dijaloga u raznim slučajevima u kojima se otvorenim ili ograničenim postupcima bez pregovora vjerojatno ne postižu zadovoljavajući rezultati u pogledu nabave. U Direktivi se ističe da se to pokazalo korisnim u slučajevima u kojima javni naručitelji ne mogu utvrditi načine zadovoljavanja svojih potreba ili nisu u mogućnosti procijeniti što se nudi na tržištu u pogledu tehničkih, financijskih ili pravnih rješenja."

Nadalje, u točki 50. uvodnog dijela Direktive stoji: »S obzirom na štetne učinke na tržišno natjecanje, pregovarački postupci bez prethodne objave obavijesti o nadmetanju trebali bi se koristiti samo u vrlo iznimnim okolnostima. Te iznimke trebale bi biti ograničene na slučajeve u kojima objava nije moguća, zbog iznimne hitnosti prouzročene nepredvidivim događajima koji se ne mogu pripisati javnom naručitelju ili na slučajeve u kojima je odmah jasno da objava ne bi dalje potaknula tržišno natjecanje ili dovela do boljih rezultata nabave i zato što objektivno postoji samo jedan gospodarski subjekt koji može izvršiti ugovor. Samo slučajevi objektivne isključivosti mogu opravdati upotrebu pregovaračkog postupka bez objave, ako slučaj isključivosti nije prouzročio javni naručitelj radi budućeg postupka nabave. Javni naručitelji koji se pozivaju na tu iznimku trebali bi obrazložiti nepostojanje razumnih alternativnih ili zamjenskih rješenja, poput upotrebe alternativnih distribucijskih kanala, čak i izvan države članice javnog naručitelja, ili uzimanja u obzir funkcijski usporedivih radova, robe i usluga. Ako je slučaj isključivosti nastao iz tehničkih razloga, ti razlozi trebaju biti točno određeni i opravdani za svaki pojedinačmi takav slučaj. Ti razlozi mogu obuhvaćati slučajeve u kojima gospodarski subjekt nema tehničkih mogućnosti za izvođenje tražene izvedbe ili potrebu za korištenjem posebnog znanja, alata ili sredstava koje posjeduje samo jedan gospodarski subjekt. Tehnički razlozi također mogu proizaći iz posebnih zahtjeva interoperabilnosti koji moraju biti ispunjeni kako bi se osigurala učinkovitost radova, robe ili usluga koje je potrebno nabaviti.« Direktiva sadržava i ovu odredbu značajnu za tržište pravnih usluga: u čl. 10. stoji da se Direktiva ne primjenjuje na sljedeće ugovore o javnoj 
nabavi (tzv. posebna izuzeća za ugovore o uslugama): usluge arbitraže i mirenja; usluge pravnog zastupanja stranke od odvjetnika u arbitraži ili mirenju u državi članici, trećoj zemlji ili pred instancijom međunarodne arbitraže i mirenja, ili sudskom postupku pred sudovima ili tijelima javne vlasti u državi članici, trećoj zemlji ili pred međunarodnim sudovima ili institucijama; usluge pravnog savjetovanja koje odvjetnik pruža tijekom pripreme bilo kojeg od postupaka navedenih u gornjoj točki ili ako postoji konkretna naznaka i velika vjerojatnost da će predmet na koji se savjet odnosi postati tema takvih postupaka; usluge ovjeravanja i certificiranja dokumenata koje moraju pružiti javni bilježnici; pravne usluge čije je pružatelje imenovao sud dotične države članice ili su imenovani za izvođenje određenih zadataka pod nadzorom tih sudova te druge pravne usluge koje su u državi članici povezane, čak i povremeno, s izvršavanjem službenih ovlasti.

Sve točke osim prve nisu se nalazile u Prijedlogu direktive na koji je CCBE dao kritiku. Dakle, popis izuzeća je proširen nakon upućene kritike. Nova Direktiva ne sadržava odredbu po kojoj su ugovori o pružanju usluga navedenih u Prilogu II. B bili podložni samo pravilima o tehničkoj specifikaciji ugovorne dokumentacije te pravilima o dostavi rezultata postupka dodjele. Umjesto u Dodatak II. B, pravne usluge svrstane su među društvene i druge posebne usluge, regulirane u glavi III (posebni režimi nabave). Tako čl. 75. određuje da javni naručitelji koji namjeravaju dodijeliti javni ugovor za društvene i druge posebne usluge obznanjuju svoju namjeru putem obavijesti o nadmetanju ili putem prethodne informacijske obavijesti. Međutim, to se ne primjenjuje ako su ispunjeni uvjeti za provođenje pregovaračkog postupka bez prethodne objave.

\subsection{Novine ZJN-2017}

ZJN-2017 usklađen je s Direktivom 2014/24/EU sa zakašnjenjem jer je rok za transpoziciju u nacionalno zakonodavstvo država članica bio do 18 . travnja 2016.

U čl. 30. navode se izuzeća od primjene Zakona. Ne primjenjuje se na ugovore o javnoj nabavi za usluge arbitraže i mirenja, usluge pravnog zastupanja stranaka od strane odvjetnika u arbitraži ili mirenju u državi članici, trećoj zemlji ili pred međunarodnom instancijom arbitraže ili mirenja, ili postupku pred sudovima, tribunalima ili tijelima javne vlasti u državi članici ili trećoj zemlji ili pred međunarodnim sudovima, tribunalima ili institucijama, zatim na usluge pravnog savjetovanja koje odvjet- 
nik pruža tijekom pripreme bilo kojeg od prije navedenih postupaka ili ako postoji konkretna naznaka i velika vjerojatnost da će pravna stvar na koju se savjet odnosi postati predmet takvih postupaka, na pravne usluge ovjeravanja i potvrđivanja dokumenata koje pružaju javni bilježnici te na druge pravne usluge koje su povezane, čak i povremeno, s izvršavanjem službenih ovlasti. Iz primjene starog ZJN-2011 bile su izuzete samo usluge arbitraže i mirenja (čl. 10.).

Poglavlje 1. glave 4. (posebni režimi nabave) drugog dijela ZJN-2017 bavi se uređenjem sklapanja ugovora o društvenim i drugim posebnim uslugama, čija je procijenjena vrijednost nabave jednaka ili veća od praga (200.000 kuna). Novo uređenje nabave pravnih usluga propisuje da javni naručitelji koji namjeravaju dodijeliti ugovor o javnoj nabavi pravnih usluga moraju objaviti obavijest o nadmetanju, koja sadržava podatke koji se zahtijevaju i za ostale postupke javne nabave. Za razliku od prijašnjeg Zakona, u novom Zakonu javni naručitelji ne mogu provoditi pregovarački postupak s prethodnom objavom poziva na nadmetanje, dok je za sektorske naručitelje ta mogućnost zadržana.

Međutim, u skladu s novom Direktivom, Zakon određuje da ako su ispunjeni uvjeti za primjenu pregovaračkog postupka bez prethodne objave poziva na nametanje, naručitelj nije obvezan objaviti poziv na nadmetanje. Naručitelj je obvezan poslati na objavu obavijest o dodjeli ugovora za pravne usluge u roku od 30 dana od dana sklapanja ugovora o javnoj nabavi ili okvirnog sporazuma (čl. 324.). Čl. 131. i 134. određuju da javni i sektorski naručitelj smiju koristiti pregovarački postupak bez prethodne objave za dodjelu ugovora o javnoj nabavi:

- ako nije podnesena nijedna ponuda ili nijedna prikladna ponuda u otvorenom ili ograničenom postupku, ili nijedan zahtjev za sudjelovanje, ili nijedan prikladan zahtjev za sudjelovanje u ograničenom postupku;

- ako samo određeni gospodarski subjekt može pružiti usluge zbog toga što je cilj nabave stvaranje ili stjecanje jedinstvenog umjetničkog djela ili umjetničke izvedbe, zbog nepostojanja tržišnog natjecanja iz tehničkih razloga ili zbog zaštite isključivih prava;

- ako iz razloga iznimne žurnosti, izazvane događajima koje javni naručitelj nije mogao predvidjeti i nisu uzrokovani njegovim postupanjem, nije moguće pridržavati se rokova propisanih za otvorene ili ograničene postupke ili natjecateljske postupke uz pregovore;

- za nove usluge koje se sastoje od ponavljanja sličnih usluga koje se dodjeljuju gospodarskom subjektu s kojim je javni naručitelj već sklo- 
pio izvorni ugovor, ako su takve usluge u skladu s osnovnim projektom za koji je bio sklopljen izvorni ugovor.

Dakle, nakon izmjena koje su uvedene novim Zakonom, javni naručitelj može birati hoće li provesti jedan od šest oblika nabave: otvoreni, ograničeni, natjecateljski postupak uz pregovore, natjecateljski dijalog, partnerstvo za inovacije i pregovarački postupak bez prethodne objave poziva na nadmetanje. Sektorski naručitelj umjesto natjecateljskog postupka uz pregovore ima mogućnost provođenja pregovaračkog postupka s prethodnom objavom poziva na nadmetanje. Posebni postupak, kakav je bio uređen prijašnjim Zakonom u čl. 44., ovdje nije definiran.

Nakon izostavljanja posebnog postupka čini se izglednim da će javni naručitelji posezati za korištenjem pregovaračkog postupka bez prethodne objave koji je najmanje transparentan od postupaka uređenih novim Zakonom. Naručitelj koji namjerava dodijeliti ugovor o javnoj nabavi u pregovaračkom postupku bez prethodne objave poziva na nadmetanje obvezan je u pisanom obliku pozvati jednog ili, ako je moguće, više gospodarskih subjekata da dostave inicijalne ponude. Inicijalnu ponudu mogu dostaviti samo oni gospodarski subjekti koje javni naručitelj pozove da dostave inicijalne ponude. Javni naručitelj potom pregovara s ponuditeljem/ima. Nakon donošenja odluke o odabiru, javni naručitelj može poslati obavijest za dobrovoljnu ex ante transparentnost na objavu, i ona ima učinak dostave odluke o odabiru. Ako to ne učini, obvezan je odluku o odabiru dostaviti ponuditeljima.

Ako se usporede posebni postupak po prijašnjem Zakonu i pregovarački postupak bez prethodne objave, koji je najmanje transparentna mogućnost koja stoji na raspolaganju javnim i sektorskim naručiteljima u javnoj nabavi pravnih usluga, uočit će se da među njima ne postoje velike razlike.

Tablica 2. Usporedba posebnog postupka po ZJN-2011 i pregovaračkog postupka bez prethodne objave poziva na nadmetanje po ZJN-2017

\begin{tabular}{|l|l|}
\hline \multicolumn{1}{|c|}{ Posebni postupak po čl. 44. ZJN-2011 } & $\begin{array}{l}\text { Pregovarački postupak bez prethodne ob- } \\
\text { jave poziva na nadmetanje po ZJN-2017 }\end{array}$ \\
\hline $\begin{array}{l}\text { Naručitelj upućuje zahtjev jednom ili većem } \\
\text { broju gospodarskih subjekata po vlastitom } \\
\text { izboru. }\end{array}$ & $\begin{array}{l}\text { Naručitelj u pisanom obliku poziva jednog } \\
\text { ili više gospodarskih subjekata po vlastitom } \\
\text { izboru. }\end{array}$ \\
\hline $\begin{array}{l}\text { Naručitelj nije obvezan javno otvoriti po- } \\
\text { nude. }\end{array}$ & $\begin{array}{l}\text { U pregovaračkom postupku bez prethodne } \\
\text { objave poziva na nadmetanje te u postupc- } \\
\text { ima dodjele ugovora za društvene i druge } \\
\text { posebne usluge otvaranje ponuda nije javno. }\end{array}$ \\
\hline
\end{tabular}




\begin{tabular}{|l|l|}
\hline $\begin{array}{l}\text { Naručitelj izrađuje zapisnik o pregledu i } \\
\text { ocjeni ponuda te odabire najpovoljniju po- } \\
\text { nudu sukladno kriteriju za odabir ponude. }\end{array}$ & $\begin{array}{l}\text { Naručitelj ocjenjuje konačne ponude te na } \\
\text { temelju kriterija za odabir ponude donosi } \\
\text { odluku o odabiru. }\end{array}$ \\
\hline $\begin{array}{l}\text { Nakon odabira naručitelj može objaviti pre- } \\
\text { thodnu obavijest o namjeri sklapanja ugovora. }\end{array}$ & $\begin{array}{l}\text { Nakon odabira, naručitelj može poslati } \\
\text { obavijest za dobrovoljnu ex ante transparent- } \\
\text { nost na objavu. }\end{array}$ \\
\hline $\begin{array}{l}\text { Ako ne objavi prethodnu obavijest o nam- } \\
\text { jeri sklapanja ugovora, donosi odluku o } \\
\text { odabiru koju dostavlja ponuditeljima. }\end{array}$ & $\begin{array}{l}\text { Ako ne pošalje na objavu obavijest za do- } \\
\text { brovoljnu ex ante transparentnost, obvezan } \\
\text { je ponuditeljima dostaviti odluku o odabiru. }\end{array}$ \\
\hline $\begin{array}{l}\text { Naručitelj je obvezan za svaki sklopljeni } \\
\text { ugovor poslati na objavljivanje obavijest o } \\
\text { sklopljenom ugovoru. }\end{array}$ & $\begin{array}{l}\text { Naručitelj je obvezan za svaki sklopljeni } \\
\text { sklopljenom ugovoru. }\end{array}$ \\
\hline
\end{tabular}

Izvor: Izradile autorice na temelju ZJN-2011 i ZJN-2017.

Također, potrebno je istaknuti da je i ZJN-2011 sadržavao odredbe o pregovaračkom postupku bez prethodne objave. Međutim, razlika od sadašnjeg uređenja jest $u$ tome što je javni naručitelj prije bio obvezan objaviti prethodnu obavijest o namjeri sklapanja ugovora ako je proveo pregovarački postupak bez prethodne objave (kada nije dostavljena nijedna ponuda ili nijedna prikladna ponuda ili nije dostavljen nijedan zahtjev za sudjelovanje u provedenom otvorenom ili ograničenom postupku, kada zbog tehničkih ili umjetničkih razloga ili razloga povezanih sa zaštitom isključivih prava ugovor može izvršiti samo određeni gospodarski subjekt te za nove usluge koje se sastoje u ponavljanju sličnih usluga koje se dodjeljuju gospodarskom subjektu s kojim je isti javni naručitelj već sklopio osnovni ugovor). Po novom uređenju prethodnog postupka, naručitelj nije obvezan poslati obavijest za dobrovoljnu ex ante transparentnost, već se na to odlučuje po vlastitom nahođenju. Dakle, iz novog Zakona izbačene su odredbe o posebnom postupku, ali su odredbe o pregovaračkom postupku bez prethodne objave vrlo slične posebnom postupku i čine ga manje transparentnim nego što je to bilo $s$ uređenjem pregovaračkog postupka bez prethodne objave po prijašnjem Zakonu.

\section{Analiza javne nabave pravnih usluga u razdoblju 2012.-2016.}

Za analizu provedenih postupaka javne nabave pravnih usluga u Hrvatskoj korišteni su podaci Elektroničkog oglasnika javne nabave, pri čemu 
su objave javne nabave pretraživane po CPV oznakama koje pripadaju pravnim uslugama. Korišteni su i podaci sudskog registra kako bi se dobile informacije o naručiteljima i njihovim povezanim subjektima te subjektima s kojima su sklapani ugovori o javnoj nabavi pravnih usluga. Nadalje, objave godišnjih financijskih izvješća Financijske agencije (RGFI javna objava izvještaja) korišteni su u analizi prihoda odabranih subjekata. Imenik Hrvatske odvjetničke komore bio je izvor podataka o broju odvjetnika, odvjetničkih ureda i društava u Hrvatskoj.

\subsection{Analiza provedenih postupaka javne nabave pravnih usluga u Hrvatskoj}

U 2016. nabavljene su uslugu u iznosu od 35.751 .629 kuna u 58 postupaka (prosječna vrijednost nabave bila je 616.407 kuna), 2015. u iznosu od 39.139.134 kuna i to u 70 postupka (prosječna vrijednosti predmeta nabave iznosila je 559.130 kuna), u 2014. u iznosu od 33.936.794 kuna u 61 postupku (prosječna vrijednost predmeta nabave bila je 556.341 kuna), u 2013. u iznosu od 65.295.132 kuna u 106 postupaka (prosječna vrijednost predmeta nabave iznosila je 615.992 kuna), a u 2012. nabavljene su pravne usluge u iznosu od 15.007.882 kuna u 56 postupka (pri čemu je prosječna vrijednosti predmeta nabave bila 267.998 kuna).

Grafikon 1. Ukupna vrijednost javne nabave pravnib usluga u razdoblju od 2012.-2016.

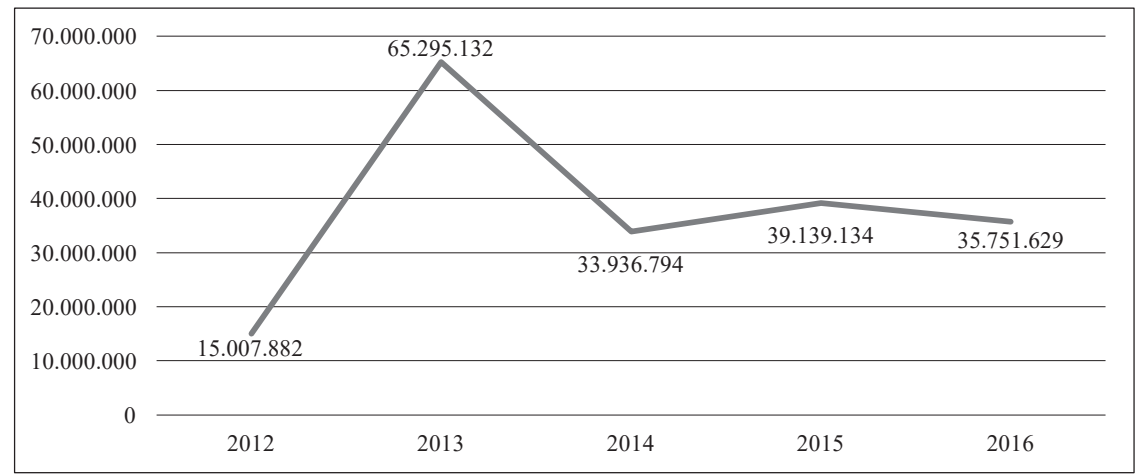

Izvor: Izračun autorica na temelju analize objava javnih nabava pravnih usluga u Elektroničkom oglasniku javne nabave (bttps://eojn.nn.br/Oglasnik/). 
Grafikon 2. Prosječna vrijednost javne nabave pravnib usluga u razdoblju 2012.-2016.

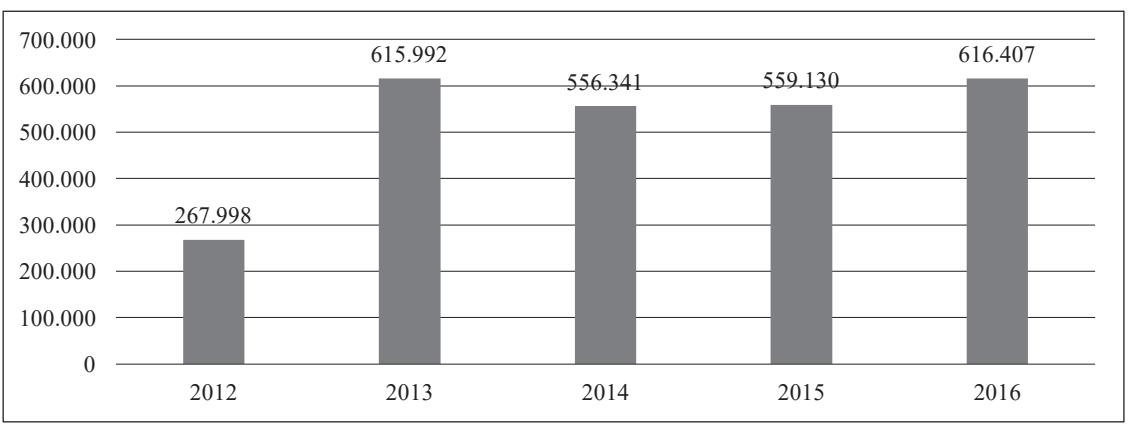

Izvor: Izračun autorica na temelju analize objava javnih nabava pravnih usluga u Elektroničkom oglasniku javne nabave (bttps://eojn.nn.br/Oglasnik/).

Pri tome, najzastupljenija je kategorija 79100000-5 Pravne usluge (205 postupaka), a potom slijede kategorija 79110000-8 Usluge pravnih savjeta i zastupanja (80 postupaka), 79112000-2 Usluge pravnog zastupanja (47 postupaka) te 79111000-5 Usluge pravnih savjeta (16 postupaka) i 79112100-3 Usluge zastupanja dionika (2 postupka) i 79120000-1 Savjetodavne usluge na području patenata i autorskog prava (1). Pravne usluge koje bi pripadale u ostalih osam kategorija nisu se pojavljivale. $\mathrm{S}$ obzirom na to da se po mišljenju Uprave za sustav javne nabave posebni postupak po čl. 44. Zakona o javnoj nabavi ne smije primijeniti na usluge koje mogu pružati i drugi ponuditelji pored odvjetnika, odnosno na one usluge koje nisu obuhvaćene tarifiranom uslugom pravnih savjeta i mišljenja (a to su usluge koje pripadaju u ostale kategorije koje se nisu pojavljivale), ne čudi da naručitelji koji žele primijeniti posebni postupak nabavljane usluge svrstavaju u navedene kategorije koje to omogućuju.

Gotovo svi provedeni postupci javne nabave pravnih usluga bili su posebni postupci po čl. 44. Zakona o javnoj nabavi. U 2016. provedena su samo četiri pregovaračka postupka (7\% postupaka u toj godini), u 2015. dva (3\% postupaka u toj godini), u 2014. pet (8\% postupaka u toj godini), u 2013. također pet (5\% postupaka u toj godini) i u 2012. dva pregovaračka postupka (4\% postupaka u toj godini). U svim promatranim godinama proveden je samo jedan otvoreni postupak javne nabave. To pokazuje da se naručitelji pravnih usluga u pravilu odlučuju za posebni postupak koji je najmanje transparentan. Svi provedeni pregovarački postupci bili su provođeni bez prethodne objave, i to većinom (80\% slučajeva) uz objašnjenje da ugovor može izvršiti samo određeni gospodarski subjekt iz tehničkih razloga. U obrazloženju tehničkih razloga naručitelji najčešće navode poznavanje ma- 
Grafikon 3. Zastuplienost kategorija pravnih usluga nabavljanib u postupcima javne nabave u razdoblju 2012.-2016.

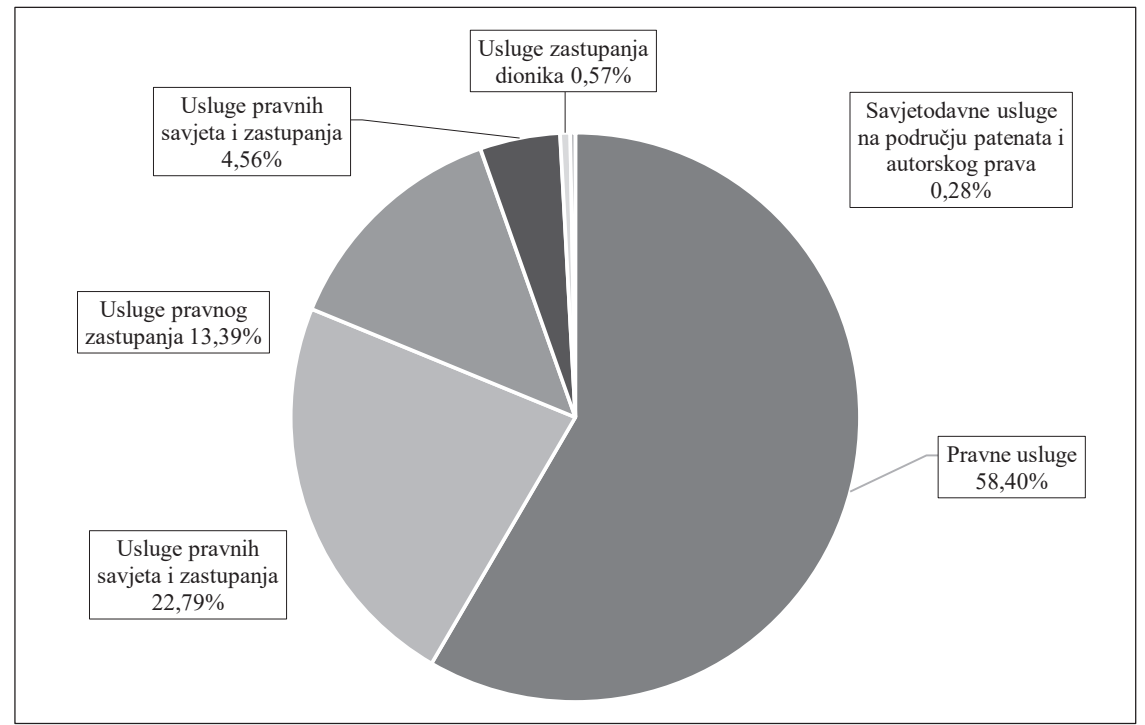

Izvor: Izračun autorica na temelju analize objava javnih nabava pravnih usluga u Elektroničkom oglasniku javne nabave (bttps://eojn.nn.br/Oglasnik/).

terije i funkcioniranja poslovanja naručitelja od odabranog gospodarskog subjekta i dugogodišnju poslovnu suradnju. U ostalim slučajevima postupak se provodio bez objave, uz objašnjenje da je riječ o novim uslugama koje se sastoje u ponavljanju sličnih usluga ili o dodatnim uslugama.

Grafikon 4. Vrste provedenib postupaka javne nabave pravnib usluga u razdoblju 2012.-2016.

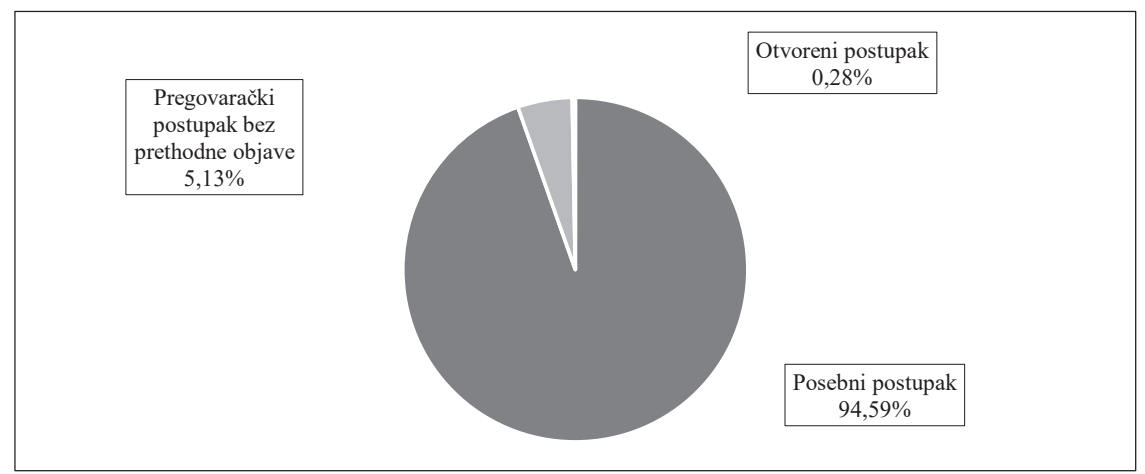

Izvor: Izračun autorica na temelju analize objava javnih nabava pravnih usluga u Elektroničkom oglasniku javne nabave (bttps://eojn.nn.hr/Oglasnik/). 
Pokazatelj transparentnosti javne nabave može se računati kao omjer vrijednosti javnih nabava koje su dodijeljene otvorenim postupkom i ukupne vrijednosti javnih nabava (Pavel, 2006.). S obzirom na to da je u promatranim godinama proveden samo jedan otvoreni postupak javne nabave, pokazatelj transparentnosti može se izračunati samo za 2013., kada je proveden otvoreni postupak javne nabave, te on iznosi 0,38, odnosno $38,29 \%$. Sljedeći pokazatelj je pokazatelj netransparentnosti, koji u omjer stavlja vrijednost javnih nabava provedenih u postupcima manje transparentnim od otvorenog postupka i ukupne vrijednosti javnih nabava (Pavel, 2012., str. 905). Tada pokazatelj netransparentnosti možemo izračunati za svih pet promatranih godina. Za sve godine, osim za 2013. (kada iznosi $61,71 \%)$, iznosi $100 \%$.

Tablica 3. Pokazatelj netransparentnosti postupaka javne nabave pravnib usluga u razdoblju 2012.-2016.

\begin{tabular}{|c|c|c|c|c|}
\hline 2012. & 2013. & 2014 & 2015. & 2016. \\
\hline $100 \%$ & $61,71 \%$ & $100 \%$ & $100 \%$ & $100 \%$ \\
\hline
\end{tabular}

Izvor: Izračun autorica na temelju analize objava javnih nabava pravnih usluga u Elektroničkom oglasniku javne nabave (bttps://eojn.nn.br/Oglasnik/).

Što se tiče broja ponuda u pojedinim postupcima javne nabave, u 2016. provedeno je šest postupaka nabave za koje je postojalo više ponuda (najveći broj ponuda u jednom postupku bio je 6), 2015. provedeno je devet nabava za koje je postojalo više ponuda (najčešće se radilo o dvije ponude, a najveći broj ponuda u jednom postupku javne nabave bio je šest), u 2014. dva postupka s više objava (najveći broj ponuda u jednom postupku bio je tri), u 2013. devet (najveći broj ponuda u jednom postupku bio je četiri), a u 2012. pet (najveći broj ponuda u jednom postupku bio je 13). U svim ostalim postupcima postojala je samo jedna ponuda za traženu/e pravnu/e uslugu/e, što posebni postupak po čl. 44. Zakona omogućuje, kao i odredbe o pregovaračkom postupku bez prethodne objave. Međutim, u čl. 44. stoji da ovisno o prirodi usluge o kojoj je riječ, uključujući i razinu tržišnog natjecanja u tom području, broj gospodarskih subjekata kojima naručitelj upućuje zahtjev za prikupljanje ponuda može biti manji od tri. S obzirom na da Imenik Hrvatske odvjetničke komore bilježi 5.148 subjekata (odvjetnika, zajedničkih odvjetničkih ureda i odvjetničkih društava), čini se malo vjerojatnim da je razina tržišnog natjecanja u području pravnih usluga niska. Načelo jednakog tretmana jedno je od načela provođenja postupaka javne nabave sadržanih u Ugovoru o osnivanju EU-a, a navedeno je i u Zakonu o javnoj nabavi, pored načela transparentno- 
sti, kao jedno od najvažnijih načela dodjele ugovora o javnoj nabavi za društvene i druge posebne usluge (čl. 325.). To se načelo može poštovati samo ako su ispunjene određene pretpostavke, a to je da svaki potencijalni natjecatelj pod jednakim uvjetima može podnijeti ponudu, da su mu dostupni kriteriji i pravila odabira te da se radi o nepristrano postavljenim kriterijima (Ljubanović \& Britvić-Vetma, str. 408). Ako je u 91\% provedenih postupaka postojala samo jedna ponuda, odnosno samo jedan ponuđač je znao za postojanje postupka te su mu bili dostupni kriteriji i pravila odabira, teško se može reći da je poštovano načelo jednakog tretmana potencijalnih natjecatelja.

Grafikon 5. Postupci javne nabave pravnib usluga po broju ponuda

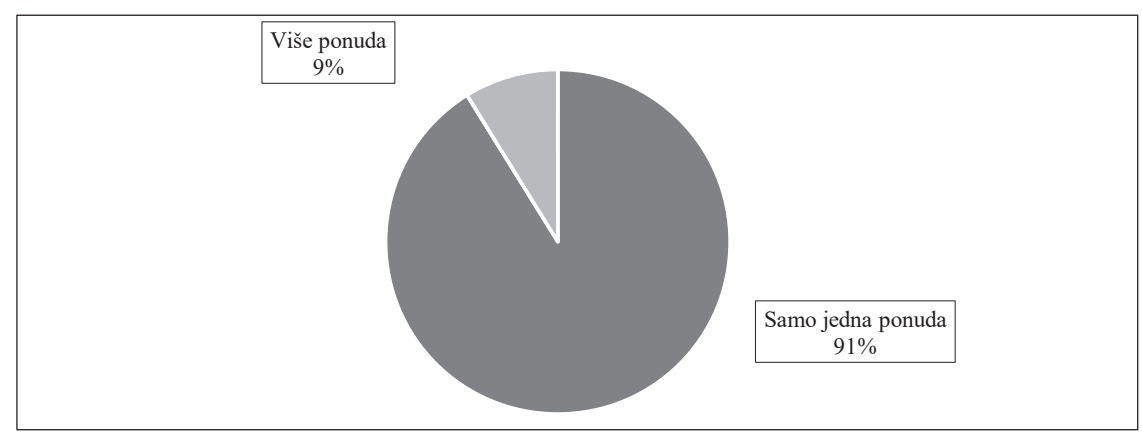

Izvor: Izračun autorica na temelju analize objava javnih nabava pravnih usluga u Elektroničkom oglasniku javne nabave (bttps:/leojn.nn.hr/Oglasnik/).

Po broju provedenih postupaka javne nabave objavljenih u Elektroničkom oglasniku javne nabave rekorder je Hrvatska elektroprivreda i povezani subjekti (HEP Opskrba, HEP Proizvodnja, HEP Trgovina, HEP Obnovljivi izori energije, Hrvatski operator tržišta električne energije, Hrvatski operator prijenosnog sustava, Plinacro) s 48 provedenih postupaka u promatranih pet godina. Slijede ih različita društva Hrvatskih željeznica (HŽ Putnički prijevoz, HŽ Infrastruktura, HŽ Cargo) s 28 postupaka. Potom dolaze Hrvatske autoceste i povezani subjekti (Hrvatske autoceste, održavanje i naplata cestarine, Hrvatske autoceste, upravljanje, građenje i održavanje, Autocesta Rijeka-Zagreb i ARZ-ON) s 21 provedena postupka. Hrvatske ceste provele su 19 postupaka, Hrvatske vode 16, a Grad Varaždin i povezani subjekti (Javna ustanova »Gradski stanovi« Varaždin, Javna ustanova »Gradski bazeni« Varaždin te VARKOM) te Grad Rijeka i povezani subjekti (KD Vodovod i kanalizacija Rijeka) također 16 postupaka svaki. Od ostalih ističu se Grad Velika Gorica i povezani subjekti (Zračna 
luka Zagreb) kao i Splitsko-dalmatinska županija i povezani subjekti s po 12 postupaka i Fond za zaštitu okoliša i energetsku učinkovitost s 10 postupaka.

S obzirom na to da velik broj provedenih postupaka ne podrazumijeva i veliku vrijednost nabave, potrebno je izraditi rang-listu po ukupnoj vrijednosti nabavljanih usluga u promatranim godinama. Na vrhu je HEP koji je nabavio usluge u vrijednosti od 34.563.012,40 kuna, a slijedi HŽ koji je nabavio usluge u vrijednosti od 27.509.607,50 kuna. Centar za praćenje poslovanja energetskog sektora i investicija na trećem je mjestu s nabavljenim uslugama pravnih savjeta u vrijednosti od 25.000.000 kuna, i to u samo jednom postupku. Potom slijede Grad Varaždin i povezani subjekti (10.225.875,50 kuna) te Grad Velika Gorica i povezani subjekti (9.049.175 kuna), Hrvatska radiotelevizija (8.284.900 kuna) i Hrvatske vode (7.787.500 kuna), Hrvatske autoceste (6.411.250 kuna), Grad Rijeka (6.168.906,25 kuna) te Hrvatski zavod za zdravstveno osiguranje (4.650.000 kuna).

Tablica 4. 10 najvećib naručitelja pravnih usluga u razdoblju 2012.-2015. po broju provedenih postupaka i ukupnoj vrijednosti javne nabave

\begin{tabular}{|c|c|c|}
\hline $\begin{array}{l}\text { Rang- } \\
\text { lista }\end{array}$ & Broj provedenih postupaka & Vrijednost javne nabave \\
\hline 1. & HEP & HEP \\
\hline 2. & $\mathrm{HŽ}$ & $\mathrm{HŽ}$ \\
\hline 3. & Hrvatske autoceste & $\begin{array}{l}\text { Centar za praćenje poslovanja } \\
\text { energetskog sektora i investicija }\end{array}$ \\
\hline 4. & Hrvatske ceste & Grad Varaždin \\
\hline 5. & Hrvatske vode & Grad Velika Gorica \\
\hline 6. & Grad Varaždin & Hrvatska radiotelevizija \\
\hline 7. & Grad Rijeka & Hrvatske vode \\
\hline 8. & Grad Velika Gorica & Hrvatske autoceste \\
\hline 9. & Splitsko-dalmatinska županija & Grad Rijeka \\
\hline 10. & $\begin{array}{l}\text { Fond za zaštitu okoliša i energetsku } \\
\text { učinkovitost }\end{array}$ & $\begin{array}{l}\text { Hrvatski zavod za zdravstveno } \\
\text { osiguranje }\end{array}$ \\
\hline
\end{tabular}

Izvor: Izračun autorica na temelju analize objava javnih nabava pravnih usluga u Elektroničkom oglasniku javne nabave (bttps://eojn.nn.hr/Oglasnik/). 


\subsection{Analiza konkurencije na tržištu javne nabave pravnih usluga}

U 62,50\% postupaka javne nabave koje je proveo HEP (i povezani subjekti), u promatranih pet godina, među odabranim subjektima ponavljalo se pet odvjetničkih društava. U slučaju HŽ-a i povezanih subjekata, pet odvjetničkih društava koje preferiraju ti naručitelji ponavljalo se u čak $96,42 \%$ postupaka. U postupcima koje su provodili Grad Varaždin i povezani subjekti u $100 \%$ slučajeva ponavljalo se šest odabranih subjekata. U 91,67\% postupaka javne nabave koje je provodio Fond za zaštitu okoliša i energetsku učinkovitost ponavljala su se tri odabrana subjekta. Hrvatska lutrija i Narodne novine u $100 \%$ provedenih postupaka angažiraju po dva ista subjekta.

Budući da navedeno upućuje na visok stupanj ponavljanja istih subjekata (bilo odvjetničkih društava, odvjetničkih ureda ili odvjetnika), promotreni su prihodi odabiranih subjekata u 2016. i 2015. od ugovora sklopljenih kroz postupak javne nabave. U 2016. udio prihoda top 10 najvećih odabiranih subjekata od ugovora sklopljenih kroz postupak javne nabave u ukupnom iznosu javne nabave pravnih usluga te godine iznosio je 48,98\%, a u 2015. i više: $61,69 \%$, u 2014. 53,37\%, u 2013. 40,81\% i u 2012. 43,61\%. Ako se navedeni udjeli u ukupnoj vrijednosti javne nabave pravnih usluga promotre kao tržišni udjeli 10 najvećih subjekata, budući da se i govori o tržištu javne nabave pravnih usluga, tada se može reći da je u 2016. koeficijent koncentracije (kao udio određenog broja najvećih subjekata na ukupnom tržištu) iznosio 48,98\%, u 2015. 61,69\%, u 2014. 53,37\%, u 2013. 40,81\%, a u 2012. 43,61\%. Vrijednosti koeficijenta koncentracije od 0-50\% upućuje na nizak stupanj konkurencije na tržištu, a između 50-60\% na postojanje oligopola. To znači da je u tri promatrane godine na tržištu postojao nizak stupanj konkurencije, a u dvije promatrane godine oligopol.

Tablica 5. Koeficijent koncentracije na tržištu javne nabave pravnib usluga u razdobliu 2012.-2016.

\begin{tabular}{|c|c|l|}
\hline Godina & Koeficijent koncentracije & \multicolumn{1}{|c|}{ Značenje } \\
\hline 2012. & $43,41 \%$ & Nizak stupanj konkurencije \\
\hline 2013. & $40,81 \%$ & Nizak stupanj konkurencije \\
\hline 2014. & $53,37 \%$ & Oligopol \\
\hline 2015. & $61,69 \%$ & Oligopol \\
\hline 2016. & $48,98 \%$ & Nizak stupanj konkurencije \\
\hline
\end{tabular}

Izvor: Izračun autorica na temelju analize objava javnih nabava pravnih usluga u Elektroničkom oglasniku javne nabave (bttps://eojn.nn.hr/Oglasnik/). 
To znači da se oko 50\% (a u 2014. i 2015. i više od 50\%) vrijednosti javne nabave pravnih usluga, koja podliježe obvezi objave u Elektroničkom oglasniku javne nabave, dijeli na 10 subjekata u Hrvatskoj. S obzirom na to da Imenik Hrvatske odvjetničke komore bilježi 5.148 subjekata (odvjetnika, zajedničkih odvjetničkih ureda i odvjetničkih društava), to znači da na $0,19 \%$ tih subjekata otpada više od pola vrijednosti javne nabave pravnih usluga.

Zanimljivo je promotriti i udio prihoda od javne nabave u prihodima odvjetničkih društava, koja podliježu obvezi objave financijskih izvještaja. Najprije je izrađena lista deset najčešće odabiranih odvjetničkih društava prema prihodima od javne nabave u relevantnoj godini. Usprkos tome što bi se u određenim slučajevima pojedini samostalni odvjetnici ili zajednički odvjetnički uredi zbog vrijednosti prihoda od javne nabave također trebali naći na listi deset najčešćih, izostavljeni su jer za njih nisu raspoloživi financijski izvještaji. Potom su u registru Financijske agencije pronađeni financijski izvještaji za svako pojedino društvo s liste deset najčešćih te izračunati udjeli prihoda od javne nabave u ukupnim prihodima. ${ }^{4}$ Tako je u 2015. prosječni udio prihoda od javne nabave deset najčešće odabiranih društava iznosio $36,47 \%$, 2014. visokih $55,50 \%, 2013.48,38 \%$, a 2012. 13,10\%. Pri tome je važno istaknuti da se udjeli prihoda od javne nabave u ukupnim prihodima pojedinih odvjetničkih društava uvelike razlikuju. Tako ima društava kojima prihodi od javne nabave čine preko $90 \%$ ukupnih prihoda u pojedinim godinama te onih kojima iz tog izvora dolazi tek 10\% ili manje ukupnih prihoda.

Tablica 6. Udio priboda od ugovora skloplienib kroz postupak javne nabave u ukupnim pribodima 10 najčešće odabiranih odvjetničkib društava

\begin{tabular}{|c|c|}
\hline Godina & $\begin{array}{l}\text { Udio prihoda od javne nabave u ukupnim prihodima } 10 \text { najčešće odabiranih } \\
\text { odvjetničkih društava }\end{array}$ \\
\hline 2012. & $13,10 \%$ \\
\hline 2013. & $48,38 \%$ \\
\hline 2014. & $55,50 \%$ \\
\hline 2015. & $36,47 \%$ \\
\hline \multicolumn{2}{|c|}{$\begin{array}{l}\text { Izvor: Izračun autorica na temelju analize objava javnih nabava pravnih usluga u Elektronič- } \\
\text { kom oglasniku javne nabave (bttps://eojn.nn.hr/Oglasnik/) i računa dobiti i gubitka objavljenih } \\
\text { u Registru godišnjih financijskih izvještaja Financijske agencije ( } h t t p: / / r g f i . f i n a . b r / J a v n a O b j a- \\
\text { va-web/prijava.do). }\end{array}$} \\
\hline
\end{tabular}




\section{Zaključak}

Novi ZJN-2017 nije zadržao mogućnost provođenja tzv. posebnog postupka u javnoj nabavi pravnih usluga, ali je zadržao i pojednostavnio odredbe o provođenju pregovaračkog postupka bez prethodne objave, koji je po svojim karakteristikama nakon posebnog postupka najmanje transparentan postupak. Također, nakon što je novi Zakon pojednostavnio odredbe u vezi s pregovaračkim postupkom bez prethodne objave, ne uočavaju se razlike između tih dviju vrsta postupaka. Novi je Zakon usklađen s Direktivom 2014/24/EU Europskog parlamenta i Vijeća o javnoj nabavi.

Ako je pružena zakonska mogućnost, javni i sektorski naručitelji u pravilu će posezati za provođenjem najmanje transparentnog postupka, ne nužno radi zloupotrebe javne nabave, već zbog veće jednostavnosti i brzine provođenja tih postupaka. Stoga ne iznenađuje da su od provedenih postupaka najčešći najmanje transparentni posebni postupci (95\%), a ostatak su pregovarački postupci. Također, ako javni ili sektorski naručitelj ima prethodna iskustva s određenim odabranim izvršiteljem pravnih usluga, ne iznenađuje činjenica da će ga ponovo odabrati te održati poslovnu suradnju. Izvršitelj koji je javnom ili sektorskom naručitelju već prije pružao pravne usluge može biti uhodan u rješavanje predmeta za naručitelja i raspolagati dobrim poznavanjem materije, pa ne iznenađuje da je u $91 \%$ provedenih postupaka postojala samo jedna ponuda, odnosno da je zahtjev za prikupljanjem ponuda bio upućen samo jednom gospodarskom subjektu, što Zakon omogućuje.

Međutim, statistička analiza pokazuje da je korištenjem najmanje transparentnih postupaka javne nabave pravnih usluga, usprkos tome što je riječ o dopuštenoj zakonskoj mogućnosti, značajno ograničeno tržišno natjecanje. Uočen je visok stupanj ponavljanja odabiranih gospodarskih subjekata. Naime, u određenim promatranim godinama više od pola vrijednosti javne nabave pravnih usluga, koja podliježe obvezi objave u Elektroničkom oglasniku javne nabave, dijelilo se na deset subjekata u Hrvatskoj. $\mathrm{Na}$ temelju njihovih udjela u ukupnoj vrijednosti javne nabave izvedeni su zaključci o tržišnoj koncentraciji, koja je u promatranom razdoblju visoka, odnosno u tri promatrane godine uočen je nizak stupanj konkurencije, a u dvije promatrane godine postojanje oligopola na tržištu javne nabave pravnih usluga. Na hrvatskom tržištu pravnih usluga prisutno je 5.148 subjekata (odvjetnika, zajedničkih odvjetničkih ureda i društava), pa u realnosti tržišna struktura odgovara monopolističkoj konkurenciji, u kojoj velik broj subjekata sudjeluje u ponudi, a proizvodi su razlučeni, odnosno međusobno diferencirani po stvarnom ili prividnom obilježju (kvaliteta, 
brzina, lokacija i sl.), pa posjedovanje određenog obilježja određenom subjektu može dati prednost pred drugim.

Iako je Zakon o javnoj nabavi potpuno formalnopravno usklađen s Direktivom 2014/24/EU, u rješenjima koje Zakon pruža i u praksi javnih naručitelja zanemarena je točka 50. uvodnog dijela Direktive, u kojoj stoji da bi se pregovarački postupci bez prethodne objave obavijesti o nadmetanju zbog štetnih učinaka na tržišno natjecanje trebali koristiti samo u vrlo iznimnim okolnostima, primjerice onda kada objektivno samo jedan gospodarski subjekt može izvršiti ugovor. Pravne usluge svrstane su u Prilog X., koji navodi kategorije društvenih i posebnih usluga, za koje se omogućuje provođenje postupka javne nabave bez objave poziva na nadmetanje. Moguće rješenje za kategoriju usluga za koju je uočen nizak stupanj konkurencije (odnosno visok stupanj koncentracije) i netransparentnost $\mathrm{u}$ javnoj nabavi moglo bi biti ispitivanje broja potencijalnih natjecatelja na tržištu te kategorije društvenih i drugih posebnih usluga te ako broj prelazi određen prag (odnosno ako nije ispunjen kriterij objektivnog postojanja samo jednog gospodarskog subjekta, što naručitelji u 80\% slučajeva navode kao razlog provođenja pregovaračkog postupka bez prethodne objave), uvođenje obveznog provođenja ograničenog postupka ili pregovaračkog postupka s prethodnom objavom umjesto pregovaračkog postupka bez prethodne objave obavijesti o nadmetanju. Drugo rješenje je određivanje većeg minimalnog broja ponuda u pregovaračkom postupku bez prethodne objave za tu kategoriju usluga (primjerice tri, a ne jedan, kao do sada). Kako je već istaknuto, tržišna struktura hrvatskog tržišta pravnih usluga odgovara monopolističkoj konkurenciji, pa bi propisivanje ograničenog postupka, pregovaračkog postupka s prethodnom objavom ili većeg minimalnog broja ponuda u pregovaračkom postupku bez prethodne objave svakako dolazilo u obzir. Međutim, budući da ne pružaju svi subjekti pravne usluge u svim granama prava, moguće je da se dogodi da u specifičnoj grani prava objektivno i postoji samo jedan gospodarski subjekt koji može pružiti adekvatne usluge. Također, moguće je da je razlog provođenja pregovaračkog postupka bez prethodne objave iznimna žurnost ili ponavljanje sličnih usluga, a ne postojanje samo jednog ponuđača. Tada bi se moglo dopustiti upućivanje ponude jednom ponuditelju (tj. provođenje pregovaračkog postupka bez prethodne objave), ali radi povećanja transparentnosti uvesti obavezno slanje obavijesti za dobrovoljnu ex ante transparentnost na objavu, što je trenutačno prepušteno diskrecijskoj odluci naručitelja. 


\section{Literatura}

Budak, J. (2008.). Ekonomske posljedice korupcije. U: Hercigonja, J. \& Kuzmić, M., Korupcija - pojavni oblici i mjere za suzbijanje. Zagreb, Hrvatska: Inžinjerski biro.

Budak, J. (2016.). Korupcija u javnoj nabavi: trebamo li novi model istraživanja za Hrvatsku?, Ekonomski pregled, 67(4), 306-327.

CCBE (2012.). CCBE Response to European Commission proposal for a directive on public procurement, 30.3.2012. preuzeto s mrežne stranice Council of Bars and Law Societies of Europe (CCBE): http://www.ccbe.eu/NTCdocument/ EN_30032012_CCBE_res1_1335171305.pdf.

Elektronički oglasnik javne nabave: https://eojn.nn.hr/Oglasnik/

European Commission (2011). Green paper on the modernisation of EU public procurement policy. Towards a more efficient European Procurement Market, COM(2011) 15 final, Brussels, 27. 1. 2011.

European Commission (2011). Proposal for a Directive of the European Parliament and of the Council on Public Procurement, Brussels, 20.12.2011, COM(2011) 0896 final - 2011/0438 (COD), SEC(2011) 1585 final.

Imenik Hrvatske odvjetničke komore: http://www.hok-cba.hr/hr/imenik.

Ljubanović, B., \& Britvić-Vetma, B. (2011.). Hrvatsko pravo javne nabave - usklađenost s pravom EU, Zbornik radova Pravnog fakulteta u Splitu, 48(2), 407417.

Pavel, J. (2006.). Public Procurement Market Transparency Indicators in the Czech Republic. Prague, Czech Republic: Transparency International.

Pavel, J. (2012.). The Situation in the Public Procurement Market in Post-Communist Countries: The Case of the Czech Republic, International Scholarly and Scientific Research \& Innovation, 6(5), 902-906.

Registar financijskih izvještaja pri Financijskom agenciji: http://rgfi.fina.hr/JavnaObjava-web.

Sudski registar: https://sudreg.pravosudje.hr/registar.

Vlahović, M. (2013.). Primjena pravila tržišnog natjecanja na odvjetničku profesiju teorijski i regulatorni aspekti - diplomski rad. Osijek: Pravni fakultet u Osijeku, preuzeto s bloga: http://legaltie.com/blog/download/radovi/Primjena-pravila-trzisnog-natjecanja-na-odvjetnicku-profesiju-Mirna-Vlahovic.pdf.

\section{Propisi}

Direktiva 2014/24/EU Europskog parlamenta i Vijeća od 26. veljače 2014. o javnoj nabavi i o stavljanju izvan snage Direktive 2004/28/EZ (SL 2014 L 94, 28. ožujka 2014., p. 65-242)

Direktiva 2004/18/EZ Europskog parlamenta i Vijeća od 31. ožujka 2004. o usklađivanju postupaka za sklapanje ugovora o javnim radovima, ugovora o javnoj 
nabavi robe te ugovora o javnim uslugama (SL 2004 L 134, 30. travnja 2004., posebno izdanje na hrvatskom jeziku, poglavlje 06, svezak 001, p. 151-235)

Priopćenje Komisije - odgovarajuće vrijednosti europskih pragova iz direktiva 2014/23/EU, 2014/24/EU i 2014/25/EU Europskog parlamenta i Vijeća (SL 2015 C 392, 25. studenoga 2015., p. 1-3)

Uredba Komisije (EU) 2015/2342 od 15. prosinca 2015. o izmjeni Direktive 2004/18/EZ Europskog parlamenta i Vijeća u vezi s pragovima primjene za postupke dodjele ugovora (SL 2015 L 330, 16. prosinca 2015., p. 18-19)

Zakon o javnoj nabavi (NN 90/11, 83/13, 143/13, 13/14)

Zakon o javnoj nabavi (NN 120/16)

\section{Sudska ili upravna praksa}

Sud EU, C-41/90 od 23.4.2991., Höfner i Elser/Macrotron GmbH, ECLI:EU: C:1991:161

Sud EU, C-309/99 od 19.2.2002.,Wouters i dr./Algemene Raad van de Nederlandse Orde van Advocaten, ECLI:EU:C:2002:98

Mišljenje i tumačenje: Primjena Zakona o javnoj nabavi na pravne usluge, Uprava za sustav javne nabave, 13.4.2012., preuzeto s http://www.hok-cba.hr/sites/ default/files/javna_nabava_pravne_usluge_1.pdf

Rješenje Ustavnog suda U-I-1085/97, U-I/23/1999, U-I-824/1999 od 20. travnja 2000., NN 51/00 


\section{PUBLIC PROCUREMENT OF LEGAL SERVICES IN CROATIA}

\section{Summary}

The paper attempts to present the characteristics of the legal framework governing the public procurement of legal services in Croatia, with a particular view to the processes at the disposal of public and sector contracting authorities. The first part of the paper analyses the provisions of the new Public Procurement Act (Official Gazette 120/16), which apply to the public procurement of legal services in Croatia, and compares these with the legal framework effective until the end of 2016. Because both laws have been harmonised with EU directives, the paper also sets forth the most significant modifications to the public procurement of legal services at EU level. In addition, the paper investigates where the Directorate for the Public Procurement System, the Constitutional Court of Croatia, and the Croatian Bar Association stand with regard to the public procurement of legal services. The previous act governing the public procurement of legal services included the option of the so-called 'particular procedure'. The new law does not include this option; however, it retains the option of negotiated procedure without prior publication of the contract notice. An analysis of the provisions of the two acts demonstrates that there is no difference between the two types of procedure, which indicates that public and sector contracting entities still bave at their disposal the option of conducting a bighly non-transparent public procurement process when it comes to legal services. The explanation provided is that these services are specific, and as such are less suited to regular public procurement processes. The second part of the paper presents the statistical analysis results regarding the public procurement of legal services in the period 2012-2016. The aim is to determine process transparency and concentration level in this period; i.e., the level of competition on the market for the public procurement of legal services. In 95\% of the cases, the contracting authorities decided to conduct the least transparent process. In the three years under observation a low level of competition was observed, while in two years an oligopoly was observed on the market for the public procurement of legal services.

Keywords: public procurement, legal services, market competition, concentration, transparency 
